\title{
Sleepiness, Insomnia, and Sleep Quality of Hospitalized Patients with Coronavirus Disease-2019: Sleep Scale Evaluation
}

\author{
Hastanede Yatarak Tedavi Alan Koronavirüs Hastalığı-2019 Hastalarında \\ Uykululuk, Uykusuzluk ve Uyku Kalitesinin Uyku Ölçekleri ile Değerlendirilmesi
}

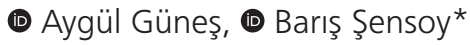 \\ University of Health Sciences Turkey, Bursa Yüksek Ihtisas Training and Research Hospital, Clinic of Neurology, Bursa, Turkey \\ *University of Health Sciences Turkey, Bursa Yüksek Ihtisas Training and Research Hospital, Clinic of Cardiology, Bursa, Turkey
}

\begin{abstract}
Objective: Sleep disorders are common and may cause accidents and inefficiencies in daily life as well as increase the risk of infection and deteriorate prognosis. This study aimed to evaluate sleepiness, insomnia, and quality of sleep with sleep scales in patients with suspected and confirmed Coronavirus disease-2019 (COVID-19) who were hospitalized for treatment.

Materials and Methods: The study was conducted in University of Health Sciences Turkey, Bursa Yüksek Ihtisas Training and Research Hospital between May and June 2020. Group 1 comprised 49 patients with a confirmed COVID-19 diagnosis on thoracic computed tomography (CT) and polymerase chain reaction test. Group 2 comprised 45 patients with a suspected diagnosis of COVID-19 on thoracic CT. The required data were collected using the Epworth sleepiness scale (ESS), insomnia severity index, and Pittsburgh sleep quality index.

Results: No significant difference was found between the confirmed and suspected disease groups, which were divided into 4 subgroups according to insomnia severity and into 2 groups according to the ESS findings. A statistically significant difference was detected between these groups concerning sleep quality $(p=0.02)$.

Conclusion: As a biopsychosocial entity, a person may be easily affected by COVID-19; hence, the consequent psychosomatic aspects of this pandemic should not be neglected and the sleep quality of patients should be thoroughly investigated.
\end{abstract}

Keywords: COVID-19, sleep quality, sleepiness, insomnia
Öz

Amaç: Uyku bozuklukları, toplumda sık görülen ve insan yaşamında kazalara, verimsizliğe ve enfeksiyon riskinin artmasına ve prognozun kötüleşmesine yol açabilen hastalık grubudur. Bu çalışmanın amacı olası ve kesin tanı alan ve hastanede yatarak tedavi alan Koronavirüs hastalığı-2019 (COVID-19) hastalarında uykuyu değerlendiren ölçekler ile uykululuk, uykusuzluk ve uyku kalitesi değerlendirilmesini yapmaktır. Gereç ve Yöntem: Bu çalışmada Mayıs-Haziran 2020'de Sağlık Bilimleri Üniversitesi, Bursa Yüksek İhtisas Eğitim Araştırma Hastanesi'ne başvurup muayene bulguları, toraks bilgisayarlı tomografi (BT) ve polimeraz zincir reaksiyonu ile kesin COVID-19 tanısı almış 49 hasta (grup 1) ve muayene ve toraks BT'de COVID-19 ile uyumlu bulguları olan olası COVID-19 tanısı almış 45 hastaya (grup 2) Epworth uykululuk ölçeği (EUÖ), uykusuzluk şiddet indeksi (UŞi) ve Pittsburgh uyku kalitesi indeksi (PUKi) uygulandı. Bulgular: UŞi'ye göre dört alt gruba ayrılan olası ve kesin COVID-19 grubu arasında uykusuzluk şiddeti açısından istatistiksel anlamlı fark yoktu. Olası ve kesin COVID-19 grubunda EUÖ puanlarına göre istatistiksel anlamlı fark saptanmadı. Olası ve kesin COVID-19 grubunda iyi ve kötü uyku kalitesine göre istatistiksel anlamlı fark saptandı $(p=0,02)$. Sonuç: Biyopsikososyal bir bütün olan insanı her yönü ile etkileyen COVID-19 pandemisinin psikosomatik yönü göz ardı edilmeyip bireylerin uykuları ayrıntılı bir şekilde sorgulanmalıdır.

Anahtar Kelimeler: COVID-19, uyku kalitesi, uykululuk, uykusuzluk

\section{Introduction}

Sleep disorders are common diseases that may lead to accidents and inefficiency in daily life, and present an increased risk of infection and deteriorating prognosis. According to the
American Academy of Sleep Medicine, sleep disorders can be examined in 8 categories which involve 85 sleep disorders. Insomnia is the most common sleep disorder, in which the individual has difficulty in falling asleep, maintaining the sleep and waking. Given the function and system of sleeping,

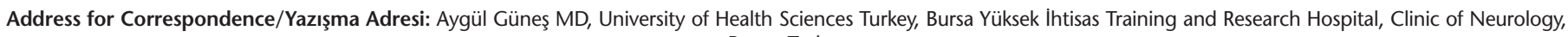
Bursa, Turkey

Phone: +90 5359249036 E-mail: doctoraynes80@mynet.com ORCID-ID: orcid.org/0000-0002-8321-4164

Received/Geliş Tarihi: 14.11.2020 Accepted/Kabul Tarihi: 08.06.2021

${ }^{\circ}$ Copyright 2022 by Turkish Sleep Medicine Society / Journal of Turkish Sleep Medicine published by Galenos Publishing House. 
insomnia can be described as conditions in which individuals cannot rest and consequently do not feel ready for a new day as they have not had sufficient sleep. According to a study of a healthy population in Turkey, insomnia was determined at the rate of $15.7 \%$ as non-relaxing sleep complaints, and at $4.9 \%$ for severe primary insomnia (1).

Another sleep disorder is hypersomnia, which is defined as unintentional sleeping and having difficulty staying awake in normal conditions during the daytime (2). Sleepiness refers to the tendency to fall asleep and may be of varying severity. In light sleep, hypersomnia is defined as unintentional sleeping in passive conditions such as resting with no attention needed. In middle sleep, it is defined as unintentional sleep, which occurs during activities that require attention such as driving cars or watching movies. Excessive sleepiness occurs unintentionally during activities such as eating or talking.

Sleep quality is the condition of feeling fresh, vigorous and ready for a new day. Sleep quality not only involves the quantitative aspects such as sleep latency (K2) (the time taken to fall asleep), duration of sleep, and the number of times the person wakes throughout the night, but also includes subjective aspects such as the depth and relaxation of sleep. Previous studies have shown that $30-40 \%$ of adults have sleep disorders while $15-35 \%$ have disorders that concern sleep quality (3-5). Sleep is not only a condition of immobility that allows the body to rest, but also a process of active regeneration that prepares the body for life over again (6).

Sleep has significant effects on the immune system. Cells of the immune system have the ability to reproduce, regenerate and recover. Therefore, it is highly important to evaluate the sleep of patients with a suspected or confirmed Coronavirus disease-2019 (COVID-19) diagnosis as sleep disorders may lead to disease progression by weakening the immune system. During the pandemic, many people may experience difficulties in concentration and sleep as a result of fear and anxiety about their own or their loved ones' health because of possible exposure to COVID-19 infection, and changes in sleeping or eating habits.

The aim of this study was to evaluate sleepiness, insomnia, and sleep quality with sleep assessment scales applied to suspected and confirmed COVID-19 patients hospitalized for treatment.

\section{Materials and Methods}

The study data were collected in University of Health Sciences Turkey, Bursa Yüksek Ihtisas Training and Research Hospital between May and June 2020. Group 1 comprised 49 patients with a COVID-19 diagnosis confirmed on thorax computed tomography (CT) and polymerase chain reaction test. Group 2 comprised 45 patients with a diagnosis of suspected COVID-19 on thorax CT.

Each patient was interviewed in detail to obtain demographic data and medical history. Patients were excluded from the study if they had a previous diagnosis of sleep disorder (insomnia, hypersomnia, obstructive sleep apnea etc.), for which they were taking drugs, had a psychopathology treated with drugs, were aged 18 years, had an advanced general condition disorder, or did not fully complete the questionnaires. It was planned to include 100 patients in the study.

The Pittsburgh sleep quality index (PSQI) is a reliable and consistent questionnaire, which is widely used to determine sleep quality in many disease groups. Validity and reliability studies of the index for use in a Turkish population were conducted by Ağargün et al. (7).

The PSQI consists of 24 items, 19 of which are completed by the patient, and 5 by a partner or roommate. In 18 of the scale items there are 7 components of subjective sleep quality (K1), K2, sleep time (K3), accustomed sleep event (K4), sleep disorder (K5), use of sleep medication (K6) and daytime dysfunction (K7). Each component is scored between 0-3, with the total points of the 7 components providing the total scale points ranging from 0 to 21 . A total score $>5$ points is evaluated as "bad sleep quality" (7).

The Epworth sleepiness scale (ESS) is a simple self-report scale, which questions the overall sleepiness level. It aims to assess the likelihood of sleeping or taking a nap in 8 different life situations (while sitting and reading a book, watching TV, sitting peacefully in a public place, travelling by car, having afternoon rest, talking with someone, sitting quietly without alcohol after lunch, stopping in a car in traffic for a few minutes). Total points $>10$ suggest a daytime sleep disorder. This is a simple, easy to understand scale for the assessment of, overall sleepiness level in adults with proven validity and reliability (8).

Insomnia was evaluated using the insomnia severity index (ISI), which was developed by Bastien et al. (9) in 2001 to assess the severity of insomnia. The validity and reliability of the ISI for a Turkish population was proven by Boysan et al. (10) in 2010. The total points are evaluated as 0-7: Clinically insignificant, 8-14: The threshold for insomnia, 15-21: Clinical insomnia (moderate level) and 22-28: Severe clinical insomnia.

The data collection form was implemented by the researchers through detailed interviews to obtain demographic data of age, gender, and marital status.

Informed consent was obtained from all the study subjects. Approval for the study was granted by the Ethics Committee of University of Health Sciences Turkey, Bursa Yüksek İhtisas Training and Research Hospital (decision no: 2011-KAEK-25 2020/05-12). All study procedures were applied in compliance with the Helsinki Declaration.

\section{Statistical Analysis}

Data obtained in the study were analyzed statistically using IBM SPSS for Windows version 22 software (SPSS Inc., Chicago, IL, USA). Conformity of the data to normal distribution was assessed using the Kolmogorov-Smirnov test. Normally distributed continuous data were shown as mean \pm standard deviation values, and data not showing normal distribution were stated as median (interquartile range) values. Continuous variables with normal distribution were compared using the independent samples t-test, and if distribution was skewed the Mann-Whitney $U$ test was applied. Categorical data were compared using the chi-square test. A value of $p<0.05$ was considered statistically significant. 


\section{Results}

Evaluation was made of 94 patients who completed the PSQI, ESS and ISI. Group 1 of 49 confirmed COVID-19 patients comprised 27 males and 22 females with a mean age of $46 \pm 18$ years. Group 2 included 45 patients with a diagnosis of suspected COVID-19, comprising 15 males and 30 females with a mean age of $56 \pm 20$ years (Table 1 ).

The two groups of confirmed and suspected COVID-19 patients were separated into 4 sub-groups according to the ISI score. A total score of 0-7 was evaluated as insignificant, 8-14 as threshold, 15-21 as moderate, and 22-28 as severe insomnia. No significant difference was determined between the 4 subgroups of the confirmed and suspected COVID-19 groups in respect of insomnia severity. In both groups, the number of patients with insignificant insomnia was much greater than those with threshold, moderate and severe insomnia (Table 2). The patients were separated into two sub-groups according to the ESS scores. Insomnia was evaluated as present with a total score of $>10$, and absent with a score of $<10$. No significant difference was determined between the confirmed and suspected COVID-19 patients in respect of the ESS scores. In both groups there was a higher rate of patients with higher sleepiness scores (Table 2).

Two sub-groups were formed according to the PSQI results evaluating sleep quality. Scores $>5$ indicated "bad" sleep quality, and scores of $\leq 5$ were evaluated as "good" sleep quality. There was determined to be a statistically significant difference between the confirmed and suspected COVID-19 patient

\begin{tabular}{|c|c|c|c|}
\hline & $\begin{array}{l}\text { Suspected } \\
\text { COVID-19 } \\
\end{array}$ & $\begin{array}{l}\text { Confirmed } \\
\text { COVID-19 }\end{array}$ & $p$ \\
\hline Male n (\%) & $15(33 \%)$ & $27(55 \%)$ & 0.04 \\
\hline Female n (\%) & $30(67 \%)$ & $22(45 \%)$ & 0.04 \\
\hline Single $\mathrm{n}(\%)$ & $12(27 \%)$ & $5(10 \%)$ & $>0.05$ \\
\hline Married n (\%) & $33(73 \%)$ & $44(90 \%)$ & $>0.05$ \\
\hline Age (years) mean $\pm S D$ & $56 \pm 20$ & $46 \pm 18$ & $>0.05$ \\
\hline
\end{tabular}

groups in respect of good or bad sleep quality $(p=0.02)$ (Table 2 ). Bad sleep quality was determined at the rate of $55.1 \%$ in the confirmed COVID-19 group, and at $31.1 \%$ in the suspected COVID-19 group.

A statistically significant difference was determined between the confirmed and suspected COVID-19 patients in respect of total PSQI scores $(p=0.02)$. In the examination of the component scores of K1, K2, K3, K4, K5, K6, and K7, no statistically significant difference was determined between the groups (Table 3).

No significant difference was found between the confirmed and suspected COVID-19 groups in respect of the overall ESS and ISI scores $(p=0.75, p=0.95)$ (Table 3$)$.

\section{Discussion}

Sleepiness, insomnia and sleep quality in patients with a diagnosis of confirmed or suspected COVID-19 were evaluated in this study using the ESS, ISI, and PSQI. Although there have been many studies investigating COVID-19 cases, very few have investigated the effect on sleep.

It was expected that a more severe level of sleep disorder according to the scales applied would be observed in the patients with confirmed COVID-19 than in the patient group with a suspected diagnosis of COVID-19.

A previous study by Huang and Zhao (11) reported that during the COVID-19 pandemic, one in three participants had symptoms of anxiety while one in five had depression and sleep disorders.

Although sleep disorders must be investigated under a broad spectrum, it is safe to say that the sleep disorder most expected to develop during an epidemic is insomnia. The implementation of quarantine to prevent the spread of infection the stigmatization of admission to hospital, and depression and anxiety may cause insomnia related problems (12).

In contrast to expectations, the current study results showed an insignificant level of insomnia according to the ISI. This finding may have resulted from the application of the scale to both patient groups in the early stages of the disease. Another reason for the insignificant level of insomnia may have been that the patients were informed about their disease in detail while they were in the hospital, together with the fact that they

Table 2. The insomnia severity scale, the Epworth sleepiness index and the Pittsburgh sleep quality index results of the patients with a diagnosis of confirmed or suspected COVID-19

\begin{tabular}{|c|c|c|c|c|}
\hline & & Suspected COVID-19 & Confirmed COVID-19 & $p$ \\
\hline \multirow{4}{*}{ The insomnia severity index } & Insignificant (0-7) & $25(55.6 \%)$ & $24(49 \%)$ & \multirow{4}{*}{$p=0.36$} \\
\hline & Threshold (8-14) & $11(24.4 \%)$ & $17(34.7 \%)$ & \\
\hline & Moderate (15-22) & $7(15.6 \%)$ & $8(16.3 \%)$ & \\
\hline & Severe $(23-28)$ & $2(4.4 \%)$ & $0(0 \%)$ & \\
\hline \multirow{2}{*}{ The Epworth sleepiness scale } & Present & $7(15.6 \%)$ & $8(16.3 \%)$ & \multirow{2}{*}{$\mathrm{p}=0.9$} \\
\hline & Absent & $38(84.4 \%)$ & $41(83.7 \%)$ & \\
\hline \multirow{2}{*}{ The Pittsburgh sleep quality index } & Good & $31(68.9 \%)$ & $22(44.9 \%)$ & \multirow{2}{*}{$p=0.02$} \\
\hline & Bad & $14(31.1 \%)$ & $27(55.1 \%)$ & \\
\hline
\end{tabular}




\begin{tabular}{|l|l|l|l|}
\hline $\begin{array}{l}\text { Table 3. Comparison of the insomnia severity index, Epworth } \\
\text { sleepiness scale and Pittsburgh sleep quality index mean scores of } \\
\text { the patients with a diagnosis of confirmed or suspected COVID-19 }\end{array}$ \\
\hline & $\begin{array}{l}\text { Suspected } \\
\text { COVID-19 }\end{array}$ & $\begin{array}{l}\text { Confirmed } \\
\text { COVID-19 }\end{array}$ & $\mathbf{p}$ \\
\hline ISI & $7.9 \pm 6.5$ & $7.8 \pm 5.9$ & 0.95 \\
\hline ESS & $4.9 \pm 4.9$ & $5.2 \pm 4.9$ & 0.75 \\
\hline PSQI-TOTAL & $5.13 \pm 3.59$ & $6.06 \pm 3.6$ & 0.02 \\
\hline PSQI-K1 & $0(0-1)$ & $1(0-2)$ & 0.20 \\
\hline PSQI-K2 & $1(0-1.5)$ & $1(0-2)$ & 0.41 \\
\hline PSQI-K3 & $0(0-0)$ & $0(0-0.5)$ & 0.15 \\
\hline PSQI-K4 & $0(0-0)$ & $0(0-0)$ & 0.55 \\
\hline PSQI-K5 & $1(1-1.5)$ & $1(1-2)$ & 0.57 \\
\hline PSQI-K6 & $0(0-0.5)$ & $0(0-0)$ & 0.68 \\
\hline PSQI-K7 & $1(1-2)$ & $1(1-2)$ & 0.19 \\
\hline
\end{tabular}

The median of PSQI K1-K2-K3-K4-K5-K6-K7 scores was identified as (25-75\%), COVID-19: Coronavirus disease-2019, ESS: Epworth sleepiness scale, PSQI: Pittsburgh sleep quality index, K1: Sleep quality: K2: Sleep latency, K3: Sleep time, K4: Accustomed sleep event, K5: Sleep disorder, K6: Use of sleep medication, K7: Daytime dysfunction

were currently being treated and trusted the healthcare system and the staff.

Another study conducted during the COVID-19 pandemic detected insomnia in $26.2 \%$ of 2065 participants (13). In a different study, a clear increase was reported in the number of patients who described insomnia symptoms, and the severity was increased in patients with a history of insomnia.

A survey based study of 14505 participants reported that $76.7 \%$ of infected patients or infection suspected patients who were in medical isolation, $51 \%$ of patients who were in self-isolation with no human contact, and $42.3 \%$ of patients who were not isolated, were identified as having sleep problems, which peaked and then started to decrease at two weeks after the isolation (14).

Similar to other pandemics, COVID-19 is apparently also causing sleep-related diseases by affecting sleep time and quality, creating difficulties in sleeping, and causing insomnia and circadian rhythm sleep disorders. Moreover, existing sleep disorders can be exacerbated.

Mirroring previous studies in literature, the results of the present study revealed that sleep quality is affected badly. The fact that the sleep quality is bad in more than $30 \%$ of the cases in both groups was a valuable discovery. Considering that there was no significant difference between the two groups in terms of insomnia and sleepiness, that there was a difference in sleep quality implies that there is the possibility of sleep disorders developing in the long term.

Moreover, the components of sleep quality; K1, K2, K3, K4, $\mathrm{K} 5, \mathrm{~K} 6$ and $\mathrm{K} 7$ were checked in sequence but no significant difference was found in either group.

Excessive daytime sleepiness (EDS) might be caused by sleep deprivation, obstructive sleep apnea, drug effects, substance use, or other medical and psychiatric causes, and rare cases of primary hypersomnia (e.g. narcolepsy, idiopathic hypersomnia) might be revealed as secondary (AASM 2014) (15). The rate of EDS cases in the current study was $15-16 \%$. Fewer cases of EDS in patients admitted to hospital is an expected finding as there are almost no conditions in the hospital environment to cause such a disorder.

It should be remembered that sleep has crucial effects on the immune system, therefore in addition to other physical complaints, patients must be questioned in detail in respect of their sleep. Cells of the immune system have the ability to reproduce, regenerate and recover during sleep. The time of day when these cells regenerate in the best way is during nocturnal sleep. A decrease in sleep time and quality has a negative effect on the immune system and this increases the risk of infection, so an effective and ample amount of sleep can improve resistance to viral infections (14). With enough sleep, the body can have the strength to protect itself from many micro-organisms, including the coronavirus.

A deterioration in sleep quality during the pandemic will make healthy individuals more vulnerable to infection and create more difficulties.

\section{Study Limitations}

It was planned to only apply sleep scales to the patients in this study. As the hospital sleep laboratory was temporarily closed because of the COVID-19 pandemic, it was planned to apply tests to patients requiring polysomnography after this period. A further limitation of the study was that the duration of symptoms and the duration of follow-up in hospital were not included in the evaluations.

\section{Conclusion}

In conclusion, the COVID-19 pandemic has resulted in detrimental effects in social, psychological, and economic aspects. As a biopsychosocial entity, a person can easily be affected by COVID-19 in every aspect and therefore the psychosomatic aspect of this epidemic should not be overlooked and patients must be evaluated in detail in respect of sleep.

\section{Ethics}

Ethics Committee Approval: Approval for the study was granted by the Ethics Committee of University of Health Sciences Turkey, Bursa Yüksek İhtisas Training and Research Hospital (decision no: 2011-KAEK-25 2020/05-12). All study procedures were applied in compliance with the Helsinki Declaration.

Informed Consent: Informed consent was obtained from all the study subjects.

Peer-review: Externally and internally peer-reviewed.

\section{Authorship Contributions}

Concept: A.G., B.Ş., Design: A.G., Data Collection or Processing: A.G., B.Ş., Analysis or Interpretation: A.G., B.Ş., Literature Search: A.G., B.Ş., Writing: A.G.

Conflict of Interest: No conflict of interest was declared by the authors.

Financial Disclosure: The authors declared that this study received no financial support. 


\section{References}

1. Aslan S, Gulcat Z, Selda Albayrak F, Maral I, Yetkin S, Sutcigil L, Aycan $S$, Isik E, Aydin H. Prevalence of insomnia symptoms: Results from an urban district in Ankara, Turkey 1. Int J Psychiatry Clin Pract 2006;10:52-8.

2. American Academy of Sleep Medicine, The International Classification of Sleep Disorders, Diagnostic and Coding Manual, 2nd ed. (ICSD2). Westchester, IL, USA. 2005.

3. Sönmez S. Vardiyalı çalışan hemşirelerde horlama, uyku bozuklukları ve iş kazaları. [Uzmanlık Tezi] Bursa: Uludağ Üniversitesi Tıp Fakültesi Göğüs Hastalıkları Anabilim Dalı; 2006.

4. Selvi Y, Özdemir PG, Özdemir O, Aydın A, Beşiroğlu L. Sağlık çalışanlarında vardiyalı çalışma sisteminin sebep olduğu genel ruhsal belirtiler ve yaşam kalitesi üzerine etkisi. Düşünen Adam Psikiyatri ve Nörolojik Bilimler Dergisi 2010;23:238-43.

5. Çalıyurt O. Sirkadiyen uyku uyanıklık düzenini etkileyen iş ve çalışma gruplarında sleep qualitynin değerlendirilmesi. [Uzmanlık Tezi] Edirne: Trakya Üniversitesi Tıp Fakültesi Psikiyatri Anabilim Dalı, 1998.

6. Karadağ M. Uyku bozuklukları sınıflaması (ICSD-2). Turkiye Klinikleri Arch Lung 2007;8:88-91.

7. Ağargün MY, Kara H, Anlar O. Pittsburgh uyku kalitesi Indeksinin geçerliği ve güvenirliği. Türk Psikiyatri Dergisi 1996;7:107-11.
8. Izci B, Ardic S, Firat H, Sahin A, Altinors M, Karacan I. Reliability and validity studies of the Turkish version of the Epworth Sleepiness Scale. Sleep Breath 2008;12:161-8.

9. Bastien $\mathrm{CH}$, Vallieres $\mathrm{A}$, Morin $\mathrm{CM}$. Validation of the Insomnia Severity Index as an outcome measure for insomnia research. Sleep Med 2001;2:297-307.

10. Boysan M, Güleç M, Beşiroğlu L, Kalafat T. Uykusuzluk Şiddeti Indeksinin Türk örneklemindeki psikometrik özellikleri. Anadolu Psikiyatri Dergisi 2010;3:242-52.

11. Huang Y, Zhao N. Generalized anxiety disorder, depressive symptoms and sleep quality during COVID-19 outbreak in China: a web based cross-sectional survey. Psychiatry Res 2020;288:112954.

12. Röhr $S$, Müller F, Jung F, Apfelbacher $C$, Seidler A, Riedel-Heller SG. Psychosocial Impact of Quarantine measures During Serious Coronavirus Outbreaks: A Rapid Review. Psychiatr Prax 2020;47:179-89.

13. Zhou J, Liu L, Xue P, Yang X, Tang X. Mental Health Response to the COVID-19 Outbreak in China. Am J Psychiatry 2020;177:574-5.

14. Mayda Domaç F, Karacı R. COVID-19 ve uyku. Nörolojik Bilimler ve COVID-19. Türkiye Klinikleri 2020;1:56-60.

15. Sateia MJ. International classification of sleep disorders-third edition: Highlights and modifications. Chest 2014;146:1387-94. 